\title{
THE EFFECT OF PROBLEM BASED LEARNING MODEL AND MOTIVATION TO LEARN PHYSICS ON STUDENT'S LEARNING OUTCOMES OF HEAT AND TEMPERATURE TOPIC IN CLASS X SMA NEGERI 1 TEBING TINGGI ACADEMIC YEAR 2014/2015
}

\author{
Agnes Mawar Yunita Sihombing dan Eidi Sihombing \\ Jurusan Fisika FMIPA Universitas Negeri Medan \\ Jalan Willem Iskandar Pasar V Medan, Sumatera Utara \\ agnesmys6@gmail.com
}

\begin{abstract}
ABSTRAK
The objectives of this research are: (1) To know difference of Problem based Learning model and Direct Intruction model to students learning outcomes in Heat and Temperature in SMA N 1 Tebing Tinggi class X Academic Year 2014/2015. (2) To determine the differences of student's that have high motivation and low motivation in the subject matter Heat and Temperature using Problem based Learning Model and Direct Instruction in Class X SMA N 1 Tebing Tinggi, Academic Year 2014/2015 (3) To know the interaction between Problem based Learning model and motivation to learn physics. The type of research was quasi experiment with the population all of student in class X of Science Program even semester in SMA N 1 Tebing Tinggi which consist of 7 classes. Sample of this research was obtained by technique cluster random sampling. The sample is X IPA 4 as the experiment class and X IPA 5 as the control class. Experiment class taught by Problem Based Learning model and control class taught by direct instruction. The research instrument has 5 questions in essay test, the instrument tested validated.the hypotheis testing uses ANOVA $2 \times 2$ and Correlation test with SPSS 17.0 software. Based on result and data analyze, the conclusion are: 1 . There is difference of Problem based Learning model and Direct Intruction model to students learning outcomes. 2. There is differences of student's that have high motivation and low motivation in Problem based Learning Model and Direct Instruction. 3 There is interaction between Problem based Learning model and motivation to learn physics.
\end{abstract}

Key word: problem based learning, motivation, student learning outcomes

\section{INTRODUCTION}

Education is one of the factors to support the progress of a country. Therefore, to improve the quality of education in Indonesia has issued in BSNP (Badan Standar Nasional Pendidikan). Based on this condition, perhaps that the students have a good learning outcomes. But the fact, it isn't same with the expectation. As the research observation result at SMAN 1 Tebing Tinggi, the learning outcomes especially in Physics is not maximum yet. It can be seen from the results of daily exams with the Kriteria ketuntasan Minimum (KKM) value of physics is 75 , while the students that are able to achieve only about $30 \%$.

The government is trying to advance education in Indonesia. These efforts can be seen from the 9-years compulsory education by providing BOS (Bantuan Operasional Sekolah) funds and also give teachers more salary by provide certification to professional teachers. In 
fact, the physics teachers in SMAN 1 Tebing tinggi already teachers certification, but still can't handle the student outcomes and still use teacher-centered learning or usually called direct instruction model.

Based the results of the survey, students whom value under the KKM must do remedial. The remedial was given only a test without giving the matter of learning. Writer proposed the implementation of remedial not only do repeated tests, but teacher must repeat the subject matter again so the student who doesn't have understand would be understood. However, the implementation of remedial, of course, will require additional time and made a new problem when the implementation schedule for the semester will end and change with the next semester and teachers are required to immediately resolve an administration preaches it.

Factors that affecting low student learning outcomes are teachers rarely use fun methods or models of learning and less variation. Teacher just explain in front of class and student only listening and take a notes, learning just focuses to physics equations and calculations than explain the basic concepts, teacher doesn't tell the relationship of physics with daily life, and the physics problems in daily life, so that students consider that physics is the hardest lesson and so difficult to understand. (Arends, 2012).

Problems above are need to overcome by develop a learning model that can improve student learning outcomes and seek student become active so in learning student not only receive what the teacher explain but also student can understand the real physics concept and no trouble in resolving the problem. The learning model must also be able to increase the motivation of students in learning. Problem-based learning (PBL) is an example of a student-centered learning environment. It was first developed in the mid-sixties of the last century in medical education with the aim to bridge the gap between what was learned in school and relevance for future professional practice. In PBL, small groups of students work together on meaningful problems under the guidance of a tutor, according to Barrows in Wijnia, (2014).

A PBL cycle generally consist of three phases: an initial problem description, discuss study phase, and a reporting phase. During the initial discussion, the problem description is usually describes a phenomenon that can be observed in daily life. Students read and discuss the problem by use of prior knowledge and common sense and eventually formulate learning issues for further self-study, which are questions that guide their self-study activities. Afterward students reporting their result discussion, according to Ajai (2013).

According to Aziz (2014) PBL allows the development of the self directed learning skill to enable students assume individual responsibility for their learning.

PBL intends to help promote students' intrinsic motivation. Impact of motivation on learning of students in education is important. In education the role of motivation is effective on students learning. Due to motivation students do any task and achieve the goal. Motivation increase speed of work and a person is doing everything to achieve goal.

Motivation to learn science benefits young students who aspire to be future scientists (Bryan, 2011). When measuring the motivation to learn science, science education researchers attempt to determine why students strive to learn science, what emotions they feel as they strive, how intensively their strive, and how long they strive. According to Glynn (2011), measuring the motivation to learn science is challenging because a construct and its components are not directly observed variables. Then he made the items components in the science motivation questionnaire were designed to serve as empirical indicators of components of students' motivation to learn science. 
Rehman (2013), according to students, teachers awrd prze when they learn well. Majority of students agreed attraction of awards motivate to learn. Teachers can encourage students when they lean well.

Motivation to do something for its own sake is mainly intrinsic, whereas motivation to do is as a means to an end is mainly extrinsic. In case extrinsic motivation, which involves learning science as a means to a tangible end, such as a career or grade. Students who are intrinsically motivated to lean often experience "flow", a feeling of enjoyment that occurs when they have developed a sense of mastery and are concentrating intensely on the task at hand, such as a lab activity, in Glynn \& Koballa (2011).

According by Gray \& Macblain (2011) when science students have the opportunity to help determine what their educational activities will be, they are more likely to benefit from them. When students lack self determination, it is difficult for them to feel intrinsically motivated. They may come to believe that their performance in a school science study is mostly uncontrollable, and as a result, they expend less effort on learning.

Based on the description above, the writer wants to see the effect of problem based learning model and motivation to learn physics on learning outcomes of Heat and Temperature topic in class X SMA Negeri 1 Tebing Tinggi Academic Year 2014/ 2015.

\section{RESEARCH METHOD}

The research has been done at Senior High School (SMA Negeri) 1 Tebing Tinggi. The populations of this research are all of students in class X SMA Negeri 1 Tebing Tinggi that consist of 7 classes of Science program. The sample is choosen by cluster random sampling. The sample is divided into two classes consisting of one class as experimental class and the other class as control class.
This research is involved two different treatments for the experimental class and the control class, where the two classes are treated differently. The experimental class treated with problem based learning model and the control class treated with direct instruction.

To determine the student's understanding of the concept, researcher use test on both classes before and after treatment, which are called pretest and posttest. The design of the research is as follows:

Table 1 Design of Research

\begin{tabular}{|c|c|c|c|}
\hline Class & Pretest & Treatment & Posttest \\
\hline Experiment & $\mathrm{T}_{1}$ & $\mathrm{X}_{1}$ & $\mathrm{~T}_{2}$ \\
\hline Control & $\mathrm{T}_{1}$ & $\mathrm{X}_{2}$ & $\mathrm{~T}_{2}$ \\
\hline
\end{tabular}

Description :

$\mathrm{T}_{1}=$ Pretest

$\mathrm{T}_{2}=$ Posttest

$\mathrm{X}_{1}=$ Learning using problem based learning model

$\mathrm{X}_{2}=$ Learning using direct instruction

The selection of data is carried out to observe whether the samples come from normal distribution population or not. The test used is Chi-Square test and Homogeneity test, by SPSS 17.

The test criteria are received Ho:the data come from a homogeneous population if $\mathrm{F}_{\text {count }}<\mathrm{F}$ table, where the $\mathrm{F}_{\text {table }}$ obtained from the distribution list $F$ with $\alpha=0.05$. Here $\alpha$ is a real level for testing.

The first and second Hypothesis Testing use ANOVA factorial $2 \times 2$ with probability level $\alpha=0,05$. The third hypothesis testing use correlation test.

Testing criteria : for another value of $\mathrm{t} \mathrm{H}_{\mathrm{o}}$ not accept, so problem based learning model has influence to the student's outcomes in learning physics.

\section{RESULT OF RESEARCH}

The results of research conducted to know students learning outcomes before the 
two of samples applied different treatments, namely the experimental class treated by using problem based learning model and control class treated by direct instruction.

From the result of research, the pre test of student in experiment and control class on score range from 0 until 100 get of mean pre test score in experiment class is 43.91 with the deviation standard is 17.99 while the mean pre test score in control class is 41.88 with deviation standard is 15.23

Based on the treatment, both of the class, experiment and control given the post test to see the ending learning ability of the students in the classes. After do the post test, experiment class has average 69.31 with deviation standard 14.99.

and in control class, the average value is 47.00 with deviation standard 19.35.

The first hypothesis testing, based on calculation of ANOVA factorial $2 \times 2$ in table 4.4 obtains the $\mathrm{P}_{\text {value }}(.000)<0.05$ for df $(31 ; 32)$ at the probability level $\alpha=0.05$. The conclusion is there is a difference learning outcomes in student learning outcomes using PBL model-based experiment and DI model-based control. The result of first testing hypothesis is also supported by the average student learning outcomes using PBL learning model-based experiment is 69.31 higher than the results of student learning using DI model that is 42.72 .

The second Hypothesis testing Anova calculation in table 4.4 also shows the $\mathrm{P}_{\text {value }}(.000)<0.05$ for $\mathrm{df}$ is $(31 ; 32)$ at the probability level $\alpha=0.05$. The conclusion there is a difference learning outcomes in student learning outcomes between high motivation and low motivation in PBL model-based experiment and DI model-based control.

The result of second testing hypothesis also supported by compare average learning outcomes using PBL model-based experiment for high motivation group and low motivation group. The average of high motivation group in PBL-based experiment is 84.6 while the average of high motivation group in DI-based experiment is 81.7. For The average of low motivation group in PBLbased experiment is 66.9 while the average of low motivation group in DI-based experiment is 60.4 .

The third Hypothesis testing obtained by the probability value (sig $\mathrm{F}$ change) $=0.016$. Because the sig $\mathrm{F}$ change is $0.016<0.05$, it means ignore Ho and approve $\mathrm{Ha}$. The conclusion is PBL and motivation are effects on learning outcomes.

In hypothesis test showed that there is different increasing of student's outcomes in experiment and control class. The student's outcomes is better in experiment class. So, can be concluded that Problem based Learning Model have effect to student's outcomes in fluid topic in class X SMA N 1 Tebing Tinggi Academic Year 2014/2015.

Although the Problem based Learning Model could improve learning outcomes, but during in teaching and learning process the Problem based Learning Model has the disadvantage, due to the weakness of researcher, the activity don't give the big contibution to the increasing of student's post test value, so for next researcher suggest to make a better descriptor to the implementation stages according to problem based learning model.

\section{CONCLUSION}

Based on the result of research data, it can be concluded that:

There is a difference learning outcomes in student learning outcomes using PBL model-based experiment and DI model-based control.

Student learning outcomes by PBL model is bigger than student learning outcomes by DI.

There is a difference learning outcomes in student learning outcomes between high motivation and low motivation. Student learning outcomes by high motivation is bigger than student learning outcomes by low motivation. 
There is interaction between PBL and motivation on learning outcomes.

\section{SUGGESTION}

According to the data of student's outcomes and the experience of research when applying the Problem based Learning Model in class, so the researcher gives suggestion as follow:

For the next researcher who wants to do research using Problem based Learning Model, pay more attention to implementation stages according to problem based learning activities and develop a better descriptor.

\section{REFERENCES}

Ajai, J. T. (2013). Comparison of The Learning Effectiveness of Problem Based Learning and Conventional Method. of Teaching Algebra. Journal of Education and Practice. ISSN 2222-1735 (paper).

Arends, R. (2012). Learning to Teach $9^{\text {th }}$ Edition. New York: Mc Graw-Hill Companies.

Aziz, M. S. (2014). The effect of Problem Based Learning on Self Directed Leearning Skills among Physics Undrgraduates. International Journal of Academic Research in
Progressive Education and Development. ISSN: 2226-6348.

Bryan, R. R. (2011). Motivation, Achievement, and Advanced Placement Intent of High School Students Learning Science. DOI 10.1002/sce 20462. Wiley Online Library.

Glyyn, S. M. (2011). Science Motivation Questionnaire II: Validation with Science Majors and Nonscience Majors. Journal of Research in Science Teaching. Vol 48. No 10 PP. 1159.

Glynn \& Koballa, (2011). Handbook of College Science Teaching. Arlington, VA: National Science Teachers Association Press.

Gray \& MacBlain. 2011. An Introduction to Learning Theories Ch-01. SAGE eBooks.

Rehman, A. (2013). The Impact of Motivation on Learning of Secondary School Students in Karachi: an Analytical Study. Educational Research International. ISSN: 2307-3721.

Wijnia, L. (2014). Motivation amd Achievement in Problem Based Learning. Netherlands: Rotterdam University 